\title{
An Investigation of the Challenges Faced by Women Entrepreneurs in Developing Countries: A Case of King Williams' Town, South Africa
}

\author{
Fortunate Mandipaka \\ Teaching and Learning Centre, University of Fort Hare \\ Email:fmandie@gmail.com
}

\section{Doi:10.5901/mjss.2014.v5n27p1187}

\begin{abstract}
This research investigates the challenges that are faced by women entrepreneurs in King Williams Town, South Africa, which can be generalised to developing countries as well. Some objectives of the study were to determine whether lack of education is a barrier to the success of women entrepreneurs, also, whether being unexposed to markets hinder the success of women entrepreneurs and women entrepreneurs are discriminated against in a male dominated society among other objectives. Indepth interviews were used to gather primary data from thirty respondents. The results indicate that family pressures hinders the success of women entrepreneurs, lack of education is a barrier to the success of women entrepreneurs, being unexposed to markets hinder the success of women entrepreneurs and women entrepreneurs are discriminated against in a male dominated society. The researcher recommends that governments of developing nations must offer financial support and mentorship programmes to women entrepreneurs. Furthermore, measures to improve access to finance by women entrepreneurs need to be undertaken, for example, government intervention in reducing discrimination from the financial institutions and help them gain access to international markets.
\end{abstract}

Keywords: developing countries; challenges; women entrepreneurs

\section{Introduction}

Entrepreneurship and business in general have been male dominated for decades, but this has changed over the years. Nowadays women empowerment has been increasing so rapidly all over the world and women are starting their own businesses to seek greater control over their personal and professional lives. It can be seen that women entrepreneurship is a growing phenomenon and has had a significant economic impact in all economies (Nieman \& Nieuwenhuizen, 2004:37).

Women entrepreneurs significantly contribute to the success of the economy. They shape and redefine the work place, business networks, financial institutions and culture. A number of initiatives have been designed to motivate women entrepreneurs. Studies show that the experience of women in business is different from those of men. There are profound gender differences in both women experiences of business ownership and the performance of women-owned firms (Carter, Anderson \& Shaw: 2001).

According to Maas and Herrington, (2006:30) as cited in the International Trade Centre (2004), Canada has experienced a 200\% growth in the number of women entrepreneurs over the last 20 years. Women-owned businesses, as reviewed by statistics in the USA, are the fastest growing sector of new business start-ups, with black women's business forming a larger share of black-owned businesses than white-owned women's businesses (Mattis, 2004:155). Within the African context, taking Cameroon as an example, women entrepreneurs manage $57 \%$ of small and microbusinesses. While in Uganda women entrepreneurs form the majority of the country's business people in the areas of farming and small to medium-sized enterprises.

Women entrepreneurs in South Africa remain on the side-lines of the national economy. Most women in business in South Africa are concentrating in the areas of crafts, hawking, personal services and the retail sector. Only a few women entrepreneurs are participating in value-adding business opportunities (Maas \& Herrington, 2006:38).

The 1995 publication of the White Paper on the Development of Small business indicated that the government in South Africa realised the importance of developing entrepreneurship and small businesses (O'Neill \& Viljoen 2001). The white paper makes reference of the development of female entrepreneurs. The main objective of the support framework of the national small business policy is to assist in the equal distribution of income, wealth and economic opportunities, with particular interest of supporting the advancement of women in all business sectors (White paper, 1995:15). This led to the improved focus on gender entrepreneurship and the growth of proper entrepreneurship interventions for gender- 
specific groups internationally.

Women-owned enterprises have their fair share of challenges and constraints that need to be addressed and specific needs have to be identified to help them perform at par, if not better, than their male counterparts. The challenges that women entrepreneurs face in South Africa have not been adequately studied and developed. This study focuses on the constraints faced by women entrepreneurs, the challenges they face, and the entrepreneurial ventures they have established in developing nations.

\subsection{Problem investigated}

According to Nieman and Nieuwenhuizen, (2004:37) customarily, a women's role has been that of mother and wife. But this has changed; women are now represented in large numbers in many business sectors. Women entrepreneurs have been the most disadvantaged group because of late they could not pursue a business activity without taking their husband or a male family member along. Although women nowadays are now engaged in the self-employment sector, many people still wonder how a woman can be a successful entrepreneur if she has gender roles to play at home, is or uneducated, unexposed to markets or cut off from financial resources, or just generally discriminated against in a male dominated society (Maas \& Herrington, 2006:4). Both men and women face difficulties in establishing an enterprise, but women are faced with specific challenges that hinder their business growth and survival. The reason why this study is being undertaken is to investigate the specific challenges faced by women entrepreneurs in King Williams Town, South Africa, a developing nation. The study will also look for possible solutions to minimise these challenges.

\section{Literature Review}

This section looks at the literature review of the challenges faced by women entrepreneurs and the theoretical framework underpinning the study.

\subsection{Evidence from past studies}

Entrepreneurs in developing nations also face unique challenges with regard to their gender. In this regard, women entrepreneurs when compared to their male counterparts are heavily subjected to barriers that create an un-conducive business environment. These barriers include gender roles at home, lack of education and training, access to financial resources, among others. The paragraphs to follow elaborate on these challenges.

\subsubsection{Gender roles to play at home}

One characteristic that differentiates most businesswomen from their male counterparts are the extra responsibilities society often put upon them in their roles as mothers and wives. Family obligations at home hinder women from becoming successful entrepreneurs in both developed and developing nations. Faced with the responsibility of having children, home duties and older dependent family members, few women can allocate all their time and energies to their business (Starcher, 1996: 8). Most financial institutions do not offer financial assistance to women entrepreneurs. The fear that exists is, they can at any time close down their business and become housewives. This result in women entrepreneurs forced to rely on their own savings, as financial capital, and loan from relatives and family friends. Married women have to make sure that they balance business and home duties for them to be successful. More-over, business success for women depends on the support the family members give to women in the process of managing of a business.

\subsubsection{Lack of education and training}

The main obstacles that women face in business are educational and work-related. Literature confirms that skills training and business education have a positive effect on enterprise performance (Akanji, 2006; Cheston \& Kuhn, 2002; Kuzilwa, 2005). It is acknowledged that the exploitation of entrepreneurial opportunity depends on the entrepreneur's level of education, skills or knowledge acquired through work experience, social network and credit (Shane, 2003). Many women entrepreneurs lack training and education both in developed and developing countries (Ibru, 2009) and hence the need for training especially in developing economies must be highlighted. Hadary (2004:4) argues that women also tend not to have the relevant education and experience in starting and managing a business and this in most cases leads to less 
potential for success. Acquiring the relevant skills and knowledge about managing a business venture can also be more difficult for women, since they then often have a double work burden and childcare responsibilities. Resultantly, women are educationally less well-equipped to manage some kinds of businesses.

\subsubsection{Lack of exposure to markets}

The ability to enter into new markets requires expertise, knowledge and contacts. Women are unable to market goods and services strategically, because they often lack access to training and experience on how to participate in business activities. Thus, women-owned SMMEs, are often unable to take on both the production and marketing of their goods (Hookimsing \& Essoo, 2003). In addition, female entrepreneurs have often not been exposed to the international market, and therefore lack knowledge about what is internationally acceptable. The high cost of developing new business contacts and relationships in a new country or market is a big deterrent and obstacle for many SMMEs, in particular women-owned businesses. According to the Commonwealth Secretariat (2002:20), women may also fear or face prejudice or sexual harassment, and may be restricted in their ability to travel to make contacts.

It is known that market liberalisation results in increased competition which demands fast response to the market. SMMEs thus face competition from transnational corporations as well as low cost producers in other developing countries. Entrepreneurs are forced to keep up with new technology and skills upgrading, and should have more wellorganized management in order to stay competitive (Nayyar et al., 2007:99). This may entail swift and easy access to extra capital, something that women entrepreneurs often lack. Thus, even when they do have professional competence and training, women are often forced to turn to male professionals for assistance.

\subsubsection{Discriminated against in a male dominated society}

Women entrepreneurs also face discrimination in a male dominated society. Being discriminated against in a male dominated society hinders women entrepreneurs from being successful. Discrimination can be defined as distinguishing unfavourably; or the detection of the difference between one thing and another. The first South African Convention for the elimination of all forms of discrimination against women defined the issue of discrimination against women, as any distinction, exclusion or restriction made on the basis of gender, which has the effect of impairing the recognition, as well as enjoyment by women (Akanji, 2006: 53).

However facts point out that it is undisputable that women business owners have been under-served by banks (Coleman, 2000). Moreover, a wider gap exists between the number of women entrepreneurs and the funding available to them, especially those who require large amount of debt. This can be explained by the fact that most businesses run by women are still small and have only operated for short periods, hence they lack the collateral and good credit records to allow them to access adequate finance from financial institutions. Evidence from previous studies shows that demand for larger sums of finance by women is less as compared to demand by men. Hence banks perceive women to be more risk averse than men, as they tend to apply for smaller amounts when seeking formal funding and generally have less access to debt finance than their male counterparts.

In global studies, it was discovered that men dominate in the SMME sector as compared to women. The research conducted by Coleman (2000) in USA reveal that men are more involved in entrepreneurial ventures than women, due to the fact that the traditional roles of women, as housekeepers and mothers could deter women the opportunity to accumulate start-up capital. The author went on to point out that women generally do not interact much and hence this results in them missing out the chances to meet potential business partners, suppliers and even promoters or financers. The findings from a comprehensive investigation of a gender-comparative nature concluded that female entrepreneurs are more likely to have less experience with financial management (Coleman 2000). These facts also further results in women not being in possession of a good credit record business financial institutions also take these issues into consideration these management skills when rationing and screening for potential recipients of credit.

\subsubsection{Face greater difficulty in acquiring capital}

Access to finance has been viewed as a biggest concern for women entrepreneurs. The challenge of accessing debt finance for most start-up women enterprises is a source of failure to women enterprises. Fielden and Davison, 2010:113) agree to the fact that women often have limited opportunities than men in accessing credit for various reasons. Some of the reasons include lack of collateral, unwillingness to accept household assets as collateral, negative perceptions about female entrepreneurs among other reasons. 
In Southern Asia, it is a fact that women are considered to be more or less invisible to formal financial institutions; and as a result they are only awarded less than $10 \%$ of commercial credits (Mahbub ul Haq human Development Center, 2000). When women do have access to credit it is often in small amounts, and financial institutions do take into consideration whether this suits their needs or not. According to Das (2001:69) divergent access to credit may of course be a reflection of differences in the choice of sector, educational level or the amount of loan requested. However, as sector choice and educational levels tend to be limited or influenced by gender, one could say that inconsistent access based on this motive is indirectly caused by gender perceptions.

As already mentioned, Das (2001:80) agree to the fact that entrepreneurs usually require financial assistance of some kind to launch their ventures - be it a formal bank loan or money from a savings account. Women in developing nations have little access to funds, due to the fact that they are concentrated in poor rural communities with few opportunities to borrow money (Starcher, 1996). As mentioned above, women entrepreneurs are suffering from inadequate financial resources and working capital, and as a result they lack access to external funds due to their inability to provide tangible security. Very few women possess tangible property.

\subsubsection{Lack of female role models}

There is a strong connection between the presence of role models and the emergence of entrepreneurs (Shapero \& Sokol, 1982). Due to the fact that women entrepreneurs have not been present as entrepreneurs in the past, they nowadays lack close role models. Role models are seen as persons that by their attitudes, behaviours and actions establish the desirability and credibility of an individual's choice to becoming an entrepreneur. Furthermore, the influence of role models is gender related. That is, an individual will be more influenced by another individual of the same gender, as one's aspirations and choices tend to be more influenced by persons of the same gender (Deaux \& Lafrance, 1998).

\subsubsection{Alfred Marshall's theory of entrepreneurship (1890)}

In his famous article Principles of Economics, Marshall asserts that there are four factors of production: land, labour, capital, and organization. A system of governance (organisation) is the key factor, which jointly coordinates the other factors, Marshall elucidates that entrepreneurship is the most important driving factor behind organization. Marshall (1994) argues that through creative organising, entrepreneurs create new products or improve the plan of producing an old produce. As a way of achieving utmost creativity, Marshall believed that entrepreneurs must be fully informed of their industries and business processes; in addition they must be natural leaders. Furthermore, Marshall's pointed out that entrepreneurs must have the ability to foresee changes in supply and demand and be willing to act on such risky forecasts in the absence of complete information. For a woman to be a successful entrepreneur she must have the following characteristics: thorough understanding of the industry; good leadership skills, and foresight on demand and supply changes and the willingness to act on such risky foresights.

Most women entrepreneurs in developing nations fail, because they lack these characteristics. Thus it becomes a challenge for them to be successful entrepreneurs. One of the short comings of this theory is that the success of women entrepreneurs however, depends not on possession of these skills, but on the economic situations in which they attempt their endeavors.

\section{Research Methodology}

This research implemented the qualitative technique. As this study was based on women entrepreneurs, the population for all registered women entrepreneurs in King Williams Town was 75 (Small Enterprise Development Agency, Eastern Cape Province). For this study, the researcher used a sample size of 30 women entrepreneurs. The data was gathered through the use of indepth interviews. The secondary data constituted a literature review of available published material. This included journals, books, Internet sources and dissertations relating to women entrepreneurs. Other relevant sources of information such as published data from Women Development Association in East London and the Small Enterprise Development Agency (SEDA) was used. Content analysis was used for the analysis of the data.

\section{Findings and Discussion}

This section of the analysis outlines the challenges that are faced by women entrepreneurs in running their businesses. The purpose of conducting qualitative research is to gain insights into the perceptions, feelings and attitudes of women 
entrepreneurs on the challenges that they face. In-depth interviews were conducted with 13 women entrepreneurs. This section analyses the data that was collected from the interviews, question by question.

The survey sought to know the obstacles that women entrepreneurs face in the day to day running of the business. More than $50 \%$ of the interviewees state that the obstacles that they face in the day to day running of their business are similar to those they encountered when starting a business. Liquidities and financial challenges are some of the obstacles. Women entrepreneurs in King Williams Town, it appears, are failing to raise enough capital to buy enough raw materials needed for the day to day operations of the business. Other notable biggest obstacle is that due to work pressure they the lack of time for training, or upgrading their skills.

The survey also included a number of questions on enterprise establishment and the challenges faced to start the business. Five interviewees inherited the business from the family or deceased spouse and eight interviewees started the business from their own. When asked what type of challenges they faced when establishing the business, $61 \%(\mathrm{~N}=8)$ of the women entrepreneurs faced challenges in raising capital to start up the business. They argued that most financial institutions easily dismiss their loan applications without proper reason of why they do not qualify to obtain a loan. They also highlighted that they also faced challenges in finding the right location for the business and the right supplier of raw materials. Finding the right personnel to help in the running of the business and finding good customers are some of the challenges that they faced. In addition, the ability to find ways to overcome competition in the business from well established businesses was their greatest challenge.

When questioned on how they overcome the obstacles they faced in establishing the businesses. Women entrepreneurs indicated that since of their loan applications were being rejected by financial institutions they resorted to borrowing cash from family and friends to start the business. Some women entrepreneurs to overcome the obstacle of finding good customer they had to engage in a lot and intensive advertisement of their business. They also cited that to overcome the obstacle of competition they looked for a sustainable competitive advantage strategy that will differentiate their products from those of competitors.

The study further sought to find out the kind of support women entrepreneurs get from the family towards the sustainability of the business.. A total of $38 \%$ reported that family members are not doing much in terms of supporting the businesses that are managed and operated by women entrepreneurs. Twenty-three per cent received help in the day to day running from family members and some families encourage them to do the business by giving them a word of hope whenever they face discrimination from male counterparts. Other women entrepreneurs claimed that their husbands help them in acquiring the resources that are required in the business and in acquiring capital from the banks.

Women entrepreneurs were asked the number of days they dedicate for business per week and how they balanced business and family work time. A noteworthy finding from the interview results is that $10 \%$ of the interviewees dedicate seven days per week to the business, $23 \%$ of the interviewees dedicate five days per week to the business and $30 \%$ of the interviewees dedicate only two days per week to the business. Despite the fact that women entrepreneurs spend much time at work most of the managed to balance business and family work. In order to create time with family they close early, while others opted to not going to work on weekends and also close during public holidays. Only a few struggle with finding better ways to balance business and family work time. This is because they fear to delegate tasks to workers in the business hence they opt to spend more time at the work than with the family.

The survey sought to understand whether women entrepreneurs have perfect knowledge of the market or type of trade you are working in. Sixty-seven per cent $(\mathrm{N}=8)$ of the respondents had no idea of the market in which they are operating in, whereas $15 \%(\mathrm{~N}=2)$ of the respondents do not have the knowledge of the current market trends in the type of trade they work in. Twenty-three per cent of the respondents could not even point out who they target customers are and where they are located.

The interviewer went further to find out whether women entrepreneurs face some discrimination against in a male dominated society when acquiring resources to use in the business and how they deal with the discrimination that they face. The majority (69\%) of the respondents indicated that they face some discrimination against in a male dominated society when acquiring resources to use in the business. To deal with this discrimination they have stopped seeing feminine gender as a weakness but as strength. They are working hard in striving to outperform male competitors. To deal with discrimination they have formed some women society where they offer each other some mentorship programmes.

When questioned on whether men discourage women entrepreneurs in their business and how does this affect their business. All women entrepreneurs were of the view that they are discouraged by men in their businesses. They were on point out the effects of the discouragement that they face. Lack of trust and confidence in themselves which made them feel that they are not good in what they are doing are some of the effects of discouragement.

The survey investigated the gender related challenges faced by women entrepreneurs. Women entrepreneurs 
pointed out that financial institution are reluctant to offer financial support to women entrepreneurs without the consent of their husbands. Some state that during maternity leave, their businesses suffer because they often remain without adequate management in the absence of them. Also, others they are harassed by the husband when the business starts to prosper and let them pay all the household bills.

Further analysis indicated that $38 \%$ of the respondents were inspired by any business women to start a business and a total of $62 \%$ of the respondents were not inspired by any business women to start the business. The started the business as a means to acquire money for them to survive with the family. Some are of the view that the need for achievement and independence motivated them to start the business.

\section{Concluding Remarks}

This research was conducted to investigate the challenges faced by women entrepreneurs in King Williams Town, South Africa. An extensive literature review on the challenges faced by women entrepreneurs and factors that motivate women entrepreneurs to start business was done. From the survey results, it can be concluded that women entrepreneurs face a lot of challenges in the business world. Many of the women entrepreneurs stressed that the challenges that they face hinders the success of their business and profitability. The following recommendations were put across based on the findings obtained from the research results.

To offer support and to encourage more women entrepreneurs to engage in business, more organisations should be established for the development of women entrepreneurs in South Africa. These organisations could support them with training and development, financing the business and other support for their entrepreneurial development. Training and development could assist women entrepreneurs to obtain management skills, including skills in preparing business plans, marketing and financial management, which could also bridge the gap in the discrimination in granting credit by the banks. In addition, awareness campaigns should be held so that women entrepreneurs could have knowledge about those organisations, with the result that they could then utilise their support and facilities. Awareness campaigns can also be held on national radio and television for women entrepreneurship training, education and networking with other women entrepreneurs. The Department of trade (DTI) should embark on a variety of initiatives to develop women entrepreneurs in South Africa. These initiatives should incorporate the nature and dynamics of women entrepreneurship, the challenges of women in business and the employment of technology for women in business. Khula, SEDA and Business Partners may partner together in offering training and mentoring programmes. The training and mentoring programmes will assist the women entrepreneurs in improving the success of their business. To curb the obstacle of pressure of childcare and the family pressures, women entrepreneurs must be taught about how to delegate tasks to employees. More nursery school should be built to minimise this kind of obstacle. The gap in lack of exposure to markets can also be fulfilled with good networking among women entrepreneurs. To ensure that their businesses progress smoothly, established women entrepreneurs should establish networks to help other women entrepreneurs. The government must also help them gain access to international markets.

\section{References}

Akanji, O, O. 2006. Microfinance As A Strategy For Poverty Reduction. Central Bank Of Nigeria Economic And Financial Review , 39 (4).

Botha, M. 2006. Measuring The Effectiveness Of The Women Entrepreneurship Programme, As A Training Intervention, On Potential, Start-Up And Established Women Entrepreneurs In South Africa. Pretoria: University Of Pretoria. (Unpublished Phd Thesis).

Carter, S., Anderson, S., \& Shaw, E. 2001. "Women's Business Ownership: A Review Of The Academic, Popular And Internet Literature". Glasgow: Department Of Marketing, University Of Strathclyde.

Cheston, S. \& Kuhn, L. 2002. Empowering Women Through Microfinance. A Case Study Of Sinapi Aba Trust, Ghana. Usa: Opportunity International.

Coleman, S. 2000. Access To Capital And Terms Of Credit: A Comparison Of Men- And Women-Owned Small Businesses.

Commonwealth Secretariat, 2002. Commonwealth Businesswomen: Trade Matters, Best Practices And Success Stories (London)

Das, M. 2001. Women Entrepreneurs From India, Problems, Motivation And Success Factors. Journal Of Small Business And Entrepreneurship.

Deaux, K., \& Lafrance, M. 1998. Gender. In D. T. Gilbert, S. T. Fiske, \& G. Lindzey (Eds.), The Handbook Of Social Psychology, Vol. 1: 788-827. Boston: Mcgraw Hill

Department Of Trade \& Industry. 2006. Draft Strategic Framework Of Gender And Women's Economic Empowerment [Online]. Available From: Http://Www.Dti.Org.Za (Accessed: 02 August 2013).

Hookoomsing \& Essoo. 2003. Seed Working Paper No. 58, Promoting Female Entrepreneurship In Mauritius: Strategies In Training And Development. International Labour Office, Geneva.

Ibru, C. 2009. Growing Microfinance Through New Technologies. Federal University Of Technology, Akure, Nigeria. 
International Finance Corporation (Ifc). 2007. Gender Entrepreneurship Markets. First Quarter Edition Global Newsletter, April.

Kuzilwa, J. 2005. The Role Of Credit For Small Business Success: A Study Of The National Entrepreneurship Development Fund In Tanzania. The Journal Of Entrepreneurship , 14 (2), 131-161.

Maas, G. \& Herrington, M. 2006. Global Entrepeneurship Monitor: South African Executive Report. Graduate School Of Business. Cape Town: University Of Cape Town.

Neumen, W.L. 2003. Social Research Methods, Qualitative And Quantitative Approaches. Boston: Allyn And Bacon Publishers.

Nieman, G.H \& Nieuwenhuizen, C. 2003. Entrepreneurship. A South African Perspective. 2nd Ed. Pretoria: Van Schaik.

Nieuwenhuizen, C. 2003. The Nature And Development Of Entrepreneurship. In G. Nieman \& J. Houg (Eds.), Entrepreneurship: A South African Perspective. Pretoria: Van Schaik.

O'neill, R.C., \& Viljoen, L. 2001. The White Paper. Support For Female Entrepreneurs In South Africa. Improvement Or Decline. Journal Of Family Ecology \& Consumer Science, Vol. 29.

Starcher, D. C. 1996. Women Entrepreneurs: Catalysts For Transformation. Retrieved July 6, 2001: Http:// Www.Ebbf.Org/Woman. $\mathrm{Htm10}$ (C2001269511)

Stoner, C.R., Hartman., \& Arora,R. 1990, Women In Small Business: Work/Home Conflict, Journal Of Small Business Management, 28(1), 38.

Women in Africa Doing Business. 2008. Case Studies Of Women Entrepreneurs Across Africa Who Have Overcome Legal And Regulatory Obstacles To Create New Business Opportunities. [Online]. Available From: Http://Www.Doingbusiness.Org/ /Media/ Fpdkm/Doing\%20business/Documents/Special-Reports/Women-In-Africa.Pdf 